\title{
The Political Economy of Inequality in Developing Countries: More Politics Than Economics
}

\author{
Silverio Zebral Filho \\ Johns Hopkins University
}

Inequality is on the top of policy agenda around the globe. Despite of the recent growing public interest around this very issue, much of the public debate is characterized by a deep misunderstanding regarding the nature, sources and idiosyncrasies of persistence inequality in developing countries. Considered primarily as an economic phenomenon primarily, policy responses use to focus on redistribution of income, assets or wealth led by the State. However, the vast majority of national governments in developing world are unable to correct market income imbalance, failing to put in place progressive taxation schemes and cash transfers in favor of the poor due to a mix of political capture by ruling elites, weak state capacity to enforce law and collect taxes and chronic fiscal debts restrain. The present article takes a different political economy-based approach of the phenomena, considering it as (mainly) a political phenomenon - that, as such, demands a political solution. The article discusses seven counter-intuitive ideas about inequality in developing countries and offers recommendations toward a more broad and effective policy agenda.

Keywords: inequality, Latin America, democracy, governance

\section{INTRODUCTION}

The major rising in productivity sparked by the Industrial Revolution in mid-XIX century across West Europe jump-started a great divergence in GDP per capita between a small group of early developed countries (mostly European) and a large group of underdeveloped (mostly in Asia and West Hemisphere) ones. Starting just before the WWI, "The Great Divergence" - as it would be called later on - will accelerate up to the mid-50s when "peripherical countries" started to bridge that gap. [Fig. 1]. Nowadays, this dynamics is characterized by the following three basic trends: (a) a recent reversal of the past divergent trend among countries due to the second globalization, the emergence of "new engines of global growth" (such China, India and Brazil) and "the rise-of-the-rest" initiated in the late-90s; (b) a growing disparities among regions with in each country: productive vanguards connected to global value chains vs. a more insular-oriented laggards regions oriented toward domestic economy and; finally, (c) a convergence among the household incomes of citizens of the same country: "the elites" vs. "the people".

Despite of this mix of trends among and within countries, both global and domestic inequalities seem to have reached the collective tolerance's tipping point. Inequality is now perceived not sole as an undesirable byproduct of accelerated growth to be managed by national governments, but as a threat to international liberal order, democracy and social cohesion to be solved by collective action. 
The 2018-2019 street protests and the unequal economic-related impacts of covid-19 on disfranchised groups have increased the urgency to solve this wicked problem of many root causes, several expressions, complex dynamics, poor metrics, persistence and rigidity through time - especially in developing world.

We understand the most promising solutions to mitigate both vertical and horizontal inequalities in developing countries suffering from chronical fiscal restraint have to tap into a domestically co-created tailor-made toolkit of policy instruments resting - mostly - outside the domain of macroeconomics. Our case goes as follows.

\section{WHY INEQUALITY MATTERS?}

Inequality affects developed (US, UK and Germany), late developed (Korea), middle-income (Brazil and South Africa) and poor countries (Bolivia, Botswana) as well. However, domestic disparities in distribution wealth and income are a sad signature malaise in late industrialized, late democratized developing countries ${ }^{1}$ during their gradual and somehow erratic transition toward being full developed democracies

Transitions to open-access orders are about inclusion; and open access to limited resources means relative scarcity and some doses of rivalry. States engages in a "race-to-the-bottom" competition for capturing FDI and connecting domestic productive vanguards with global value chains. Political elites dispute de facto power to assigns rents to buy electoral loyalties to remain in de jure power. Interest/identity groups tries to shape public decision-making accordingly their interest and ideas to capture fiscal resources to fund their own goals.

If perceived as high, persistent and unfair - and, in spite of that - left without treatment - inequality feed more of competition then collaboration among actors. When off limits, fierce competition has potential to meltdown interpersonal trust and social cohesion, destabilize elite-bargaining regimes and impair individual/property rights required by developing economies to thrive [North, 2009].

\section{INEQUALITY: 7 COUNTER-INTUTIVE IDEAS}

\section{Idea \# 1: Inequality is a Process, Not a Result}

Inequalities are embedded in multiple interactions among unequal actors collaborating, competing and/or conflicting strategically to capture unequally distributed resources and capacities and use them in favor of their own priority goals under a path-dependent ("sticky") institutional framework limiting choices and chances of alternative courses-of-action available. Formal (rules, hierarchies, authority, nationality) and non-formal institutions (norms, status, leadership, identities) shape interactions in a way that a complex (semi)spontaneous order emerges - just to be, at least in theory, tutored by a special actor holding de jure monopoly of legit use of violent coercion to preserve peace and the "status quo": The State.

Institutional stickiness is not destiny: actors can promote institutional change by changing their own strategies, alliances, interest, ideas and goals through time [Fig.2]. In this sense, the interplays between actors holding unequal levels/types of power (hard, soft) and sticky-but-dynamic institutions are to key to understand, for instance, why specific political regimes adopt specific types of growth strategies and how growth trajectories generate different levels/types of inequality.

\section{Idea \# 2: Inequality is Not (only) About Money}

In developed world, income/wealth inequality can be reduced by taking from "the elites" (progressive taxes) and giving to the poor (cash transfers). However, state capacity to monitor and punish tax evasion is particularly low in developing countries and high progressivism is not politically feasible where public service provision is poor. Inflation, added-value taxes, and higher marginal propensity to consume among the poor drains the purchasing power of cash transfers. In developing countries, multidimensional inequality is deeper and more persistent [Fig. 3]. It can be mitigated only by a comprehensive reform of public expenditure structure and appropriations (access to higher education, health services provision, job protections), major capital investments to equalize living standards (housing, sanitation, electricity) 
affecting human capabilities accumulation and removal of legal barriers that perpetuates horizontal inequalities (gender, race, religion) under the Law.

\section{Idea \# 3: Inequality is Not Destiny}

The fact that most of developing countries were colonies during early years of statehood implied that state apparatus and assets were organized to serve colonizers' exploitation goals. Colonial formal institutions (military occupation, slavery, colonial pact) are now gone, but legacies of colonial norms (dominance, identity, patrimonialism) still can be found in contemporary unequal distribution of property (land ownership) and unequal treatment under the Law (privileges, discrimination and affirmative actions according race, ethnicity, nationality, gender, identity, social status and political prestige) ${ }^{2}$. Nevertheless, international experience indicates that former colonies preserve a great deal of autonomy for bridge these gaps - even under hybrid political regimes. South Korea's (agrarian reforms in 60s, investment in education in the 70s, technological catch-up in the 80s) and Bolivia (commodities super cycle in 00s funding targeted transfers in 10s) are good examples of collaboration among "the elites" (politicians, entrepreneurs and technocrats) in favor of "the people" resulting in a state performance capable to conciliate growth and inclusion. South Africa and Vietnam are examples of the opposite.

\section{Idea \# 4: Inequality is a Political Decision}

Take US and Germany as example: market-income inequality levels and tax progressiveness are similar in both countries. Lower levels of disposable income inequality in Germany results from more progressive and generous social transfers and welfare benefits [Fig. 04]. In developing countries, income inequality largely depends of distributional choices made by political elites to survive. Discretional assignment of rents is the currency of politics in many countries and corruption is the price of governability when political fragmentation is high. In hybrid regimes, "stationary bandits" pass-through just a tiny part of the national income downwards in order to preserve the status quo (with or without a degree of circulation of elites) uncontested by rival groups and unchallenged by the poor This arrangement offers enough credible commitment to foreign capitals looking for financial arbitrage or joint-venturing opportunities. While granting plenty of de jure voice space to mitigate exit, elites carefully "feed their prey" and choose winners and losers in the rent-seeking game to preserve its own power [Olson,1993].

\section{Idea \# 5: Market Does Not Generate Inequality but Reveals and Reproduces It}

Market forces rewards previous inequalities in accumulated human/social capital (schooling, knowhow and know-who), some related to early-childhood development (nutrition, cognition, family status, parental care, psychological safety $)^{3}$, allocating incomes accordingly. As we saw, governments can try to reduce income inequality using taxes and transfers, but the only sustainable way forward is equalizing initial conditions and grating equality of opportunity at the life cycle point where attainment of these capacity pays highest premium [Romer, 2013]. For instance, market does not always offer higher premium on wages to employees with higher levels of education. Returns on educational attainment depends schooling years associated with the specific tacit knowledge ("knowhow") demanded by international/domestic strategies taken by each country ${ }^{4}$.

\section{Idea \# 6: Accelerated Growth Favors High Inequality}

Wealth accumulation systems are somehow faster than wealth distribution's market-based or discretionary ones ${ }^{5}$. Accelerated growth disproportionally assigns profits to more productive actors and rents to well-connected groups. Moreover, accelerated growth tends to be more volatile and prone to more frequent and deep episodes of recessions [Fig. 05]. Recession disproportionally affects the poorest among the poorer that are vulnerable to negative fluctuations once facing job insecurity, lacking savings and holding insecure property rights over "dead capital" that cannot be collateralized. Economic complexity affect inequality as well. Product diversification strongly correlates with lower levels of inequality. Commodities-export growth is prone to resources curse and Dutch disease, reducing real wages in nonexport blue-collar industrial sector and demands generous (re)distribution policies for rebalancing. High 
inequality has adverse effects over many domestic growth sources impairs productivity, elevate capital costs by narrowing borrowing-base, put pressure on already tight budget and overdemand public services.

\section{Idea \# 7: People do not care (that much) About Inequality}

There is no doubt that inequality matters a lot in a lot of domains. High levels of inequality are strongly correlated with lower levels of interpersonal trust [Fig. 06]. Besides of being a key element of social cohesion, interpersonal trust reduces transaction, coordination and information costs of commutative contracts. Counterintuitively, recent research suggests citizens in unequal societies are less concerned about inequality then those in more egalitarian ones. Growing inequality does not seem to affect societal belief in meritocracy ${ }^{6}$. High vertical inequalities can be kind of "naturalized" when income, wealth or prestige are perceived to be acquired by merit, overcoming adverse initial conditions [Mijs, 2019]. Even though of being strongly correlated with inequality, crime victimization, safety perception in developing world is more frequently attributed to with distrust on law enforcement agents. In a nutshell, inequality desperately need a PR campaign.

\section{TAMINIG INEQUALITY: More Politics Than Economics}

Governments can take measures to mitigate inequalities by both affecting its structural sources or compensating those who were left behind by facing adverse initial conditions and circumstances. Distributive policy instruments vary among nations, but the vast majority of developing countries does not have the fiscal space to insist on permanent compensatory poverty-alleviation type measures such as targeted cash transfers or basic income benefits.

In developing countries, taming inequality requires a broader agenda, including measures in other policy domains, such as human rights, household living conditions and open governance, as follows:

[1] Self-reinforcing vicious cycle of inequality affect the leveling of playing field and the ability of the players - no matter what rules-of-the-game are in place. At individual level, horizontal inequalities tilt the playing field against disenfranchised groups. Effective interventions must remove barriers faced by them to access of civil and political rights (same-sex marriage, migrant's vote), granting equal treatment under the Law. Horizontal inequality is deontologically unacceptable and a key pilar of pluralist societies. Recognition of cultural and identity rights has fiscal costs, but reductions in some horizontal inequalities spills overs income/wealth and promise more durable, less costly and more permanent results than cash transfers. In sum, human rights protection, promotion and protection are conductive to less inequality.

[2] Major differences during early-childhood development (cognitive, nutrition, health) affect the ability of the players to make better choices during the game. Literature on early-childhood development is vast and many behavioral-informed field experiments are available to inform tailor-made interventions in line with local conditions. Equalizing household inequalities affecting infants can be tricky, but certainly less expensive than targeting adults later on.

[3] At societal level, inequalities of all types feed populism and polarization if perceived as results of unfair "rules-of-the game" by the majority of the players. Cash transfers or universal basic income programs release some hot air and preserve order - just while social cohesion cracks "under-the-radar". Gender-based budget planning and policy appraisals focusing on distributional effects of public projects are examples of useful public management tools to initiate structural reform of social expenditure in developing countries [UNDP, 2020].

[4] Developing countries should not emulate distributional policies of advanced ones. International standards and peer-review mechanisms offer some ideas space for policy design, but policy adaptation is limited by fiscal space, state capacity and local political settlements. Policy receipts (Washington Consensus) and conditionalities (IMF) failed in the past due to disregard of governance, reform fatigue or nativism. Policy transplants often do not stick in different institutional context (how about a private-only health system to replace NHS in UK, uh ?!). 
Distributional polices must consider country-specific sources of inequality: race in South Africa, caste system in India, middle-class capture in Brazil, and regional imbalances in China. Isomorphic mimicry solutions just masks "status quo" preservation under cosmetic changes. Good-fit second-best solutions co-designed under open governance arrangements (participatory budgets, social oversight, public-private alliances) are preferred than best practices validated abroad. In sum, there's no once-size-fits-all solution.

[5] Developing countries must seize the opportunity of having a less consolidated institutional framework to reform public governance as a way to pursue own social policies to mitigate own inequalities. There's no doubt that representative democracy is in crisis, but deliberative democracy is vivid at local level. Angry and resentment showcased during 2018-2019 street protests must be transform in energy and channeled to demand better accountability systems. Deep and frequent civic engagement in policy design and social oversight of implementation at local level feed ownership of rights and compliance with duties toward the polity [Innerarity, 2018]. Precautionary measures to avoid decision-making capture by social minorities becoming political majorities and civic education to deal with complex policy dilemmas and trade-offs are key elements for an effective democracy with low levels of inequality.

\section{ENDNOTES}

1. Latin America and the Caribbean (LAC) is one of the most unequal regions in the world in terms of household income: the richest $10 \%$ of the population captures 22 times more of the national income than the poorest $10 \%$, on average. For more on inequality in LAC countries, see IDB (2020).

2. For instance, criminal law grants elected politician holding public office special treatment during prosecution even when charges are not related with the public mandate. college-degree holders special incarceration regime in Brazil.

3. See Nobel Prize's winner Prof. James Heckman's website for a large repository of early childhood development and inequality at www.heckmanequation.org

4. In Brazil, inward-oriented growth pays higher premiums on wages to white-collars college-degree holders, grant them social status and some legal privileges. In Germany, outward-oriented growth based on exports of high-value added industrial goods pays higher premiums on wages go to high-skilled blue-collars workforce graduated from technical schools

5. Maybe in part for the higher transaction and coordination costs to build political consensus on the latter should be organize and managed properly.

6. For a different take on the perils of meritocracy, see Sandel (2020).

\section{REFERENCES}

Bolt, J., Inklaar, R., et al. (2018). Maddison Project Database. Retrieved from https://www.rug.nl/ggdc/historicaldevelopment/maddison/releases/maddison-project-database2018

Busso, M., \& Messina, J. (2020). The Inequality Crisis: Latin America and the Caribbean at the Crossroads (1st edition). Washington-DC: Interamerican Development Bank.

DOI:http://dx.doi.org/10.18235/0002629

Gonzales, F. (2020, September 10). Main elements of political economy analysis. SAIS/JHU ICPEDC.

Innerarity, D. (2018). Compreender la Democracia. Capítulo 1: La democracia de los incompetentes (1st edition). Barcelona: Gedisa Editores.

Mijs, J.B. (2019). The paradox of inequality: Income inequality and belief in meritocracy go hand in hand. Socio-Economic Review, pp. 1-29. Doi:10.1093/ser/mwy051

Milanovich, B. (2019) Capitalism Alone: the future of the system that rules the world (1st edition). Cambridge: Harvard University Press.

North, D., Walls, J., \& Weingast, B. (2009). Violence and Social Orders: a conceptual framework for interpreting recorded human history (1st edition). New York: Cambridge University Press. 
Olson, M. (1993, September). Dictatorship, Democracy, and Development. American Political Science Review, 87(3).

OPHI. (2014). The Multidimensional Poverty Index. Retrieved November 3 2020, from https://ophi.org.uk/multidimensional-poverty-index.

Romer, J. (2013, October). Equality of opportunity. Cowles Foundation Discussion Paper no. 1921. Yale University Department of Economics.

Sandel, M., Farrar, S., et al. (2020). The Tyranny of Merit: What's become of the common good? (1st edition). New York: Macmillan.

UNDP. (2020, December). Documiento base de estratégias para políticas integrales para la cohesion social en América Latina y el Caribe. Madrid: UNDP and AECID.

\section{ANNEX}

\section{THE GREAT DIVERGENCE (1800-2012)}

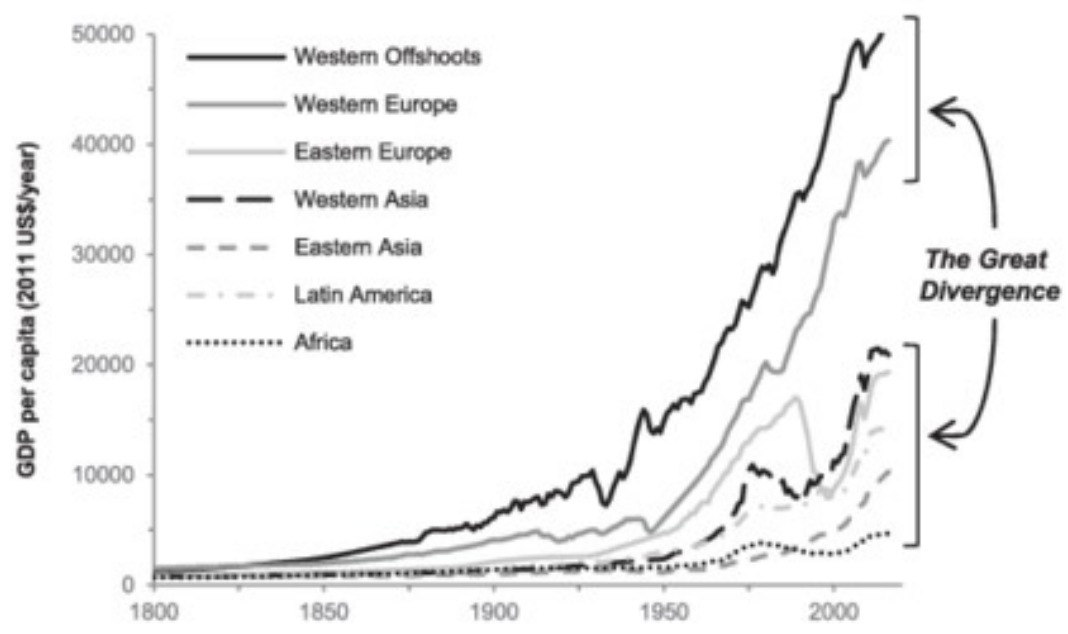

Source: Bolt at all (2018). Developing countries in Asia and Africa start to bridge the gap in late80s-90s. But differences in GDP per capita among developed and developing countries are still very relevant. 
FIGURE 2

INTERPLAY BETWEEN INTERACTIONS AMONG UNEQUAL ACTORS, (SEMI) STICKY PATH-DEPENDENT INSTITUTIONS AND INEQUALITIES

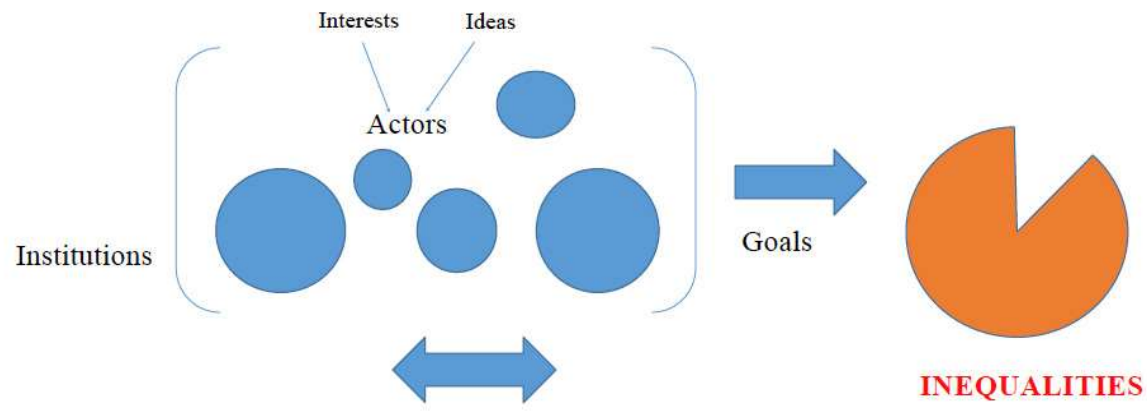

Interactions

Source: Gonzales (2020). Power is represented by the size of blue circles. Blue arrow titled "Goals" represents the net result among complementary and conflicting goals among actors.

FIGURE 3

MULTIDIMENSIONAL POVERTY (AND INEQUALITY) INDEX - BASIC DIMENSIONS

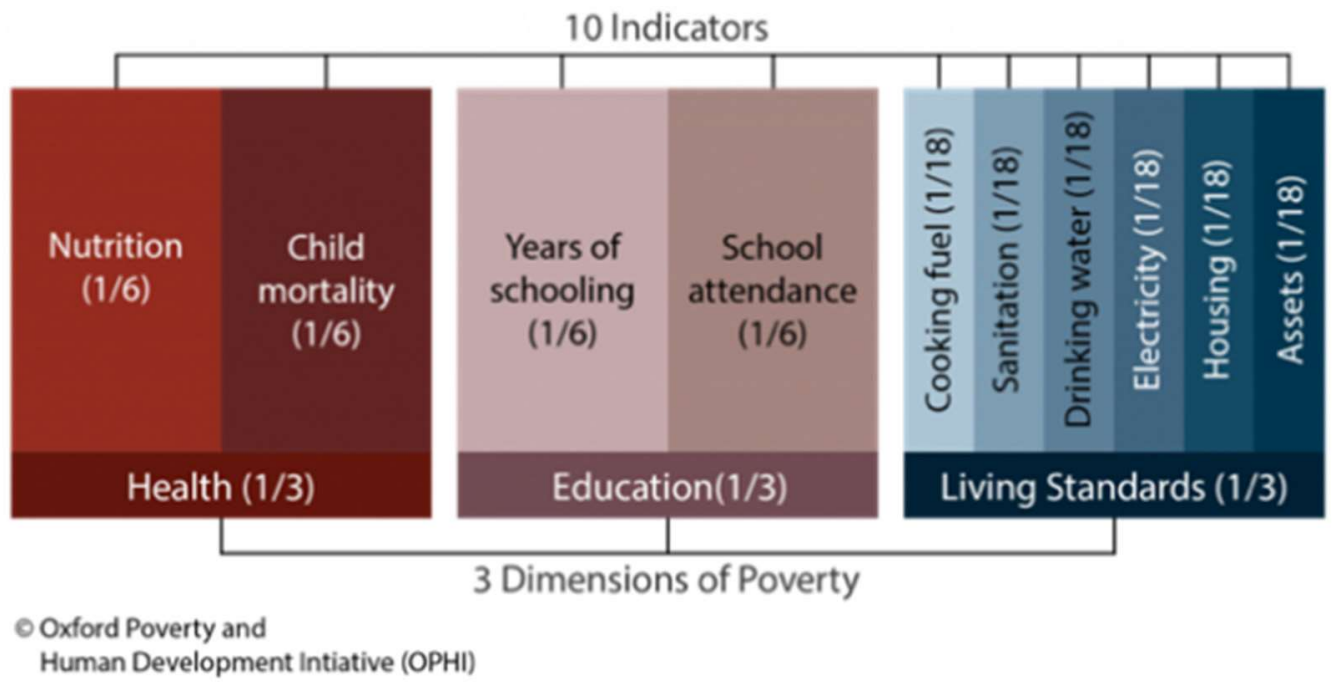

Source: OPHI (2014). Health-related indicators refer to early-childhood. Education-related indicators refer to infants and teenagers. Living standards indicator relates to entire household environment - affecting adequate development of human capabilities of all family members. 


\section{FIGURE 4}

\section{INCOME INEQUALITY AFTER REDISTRIBUTION POLICIES (TAX AND TRANSFERS)}
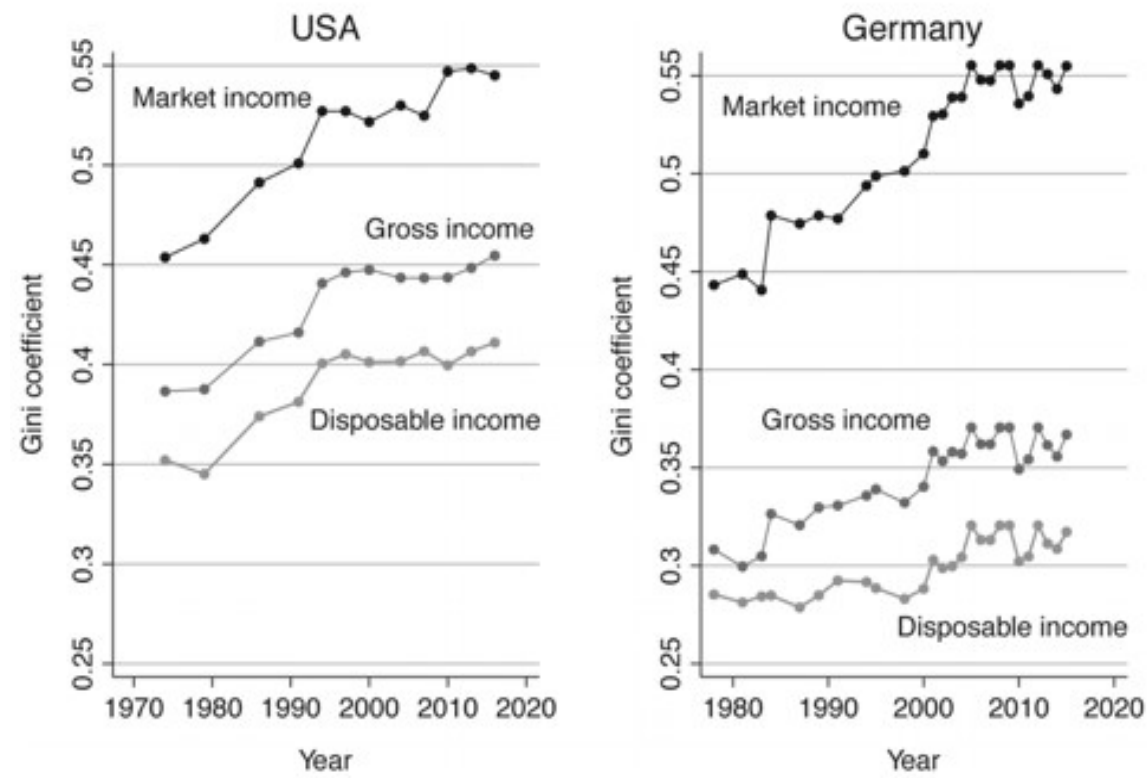

Source: Milanovich (2019, pg. 38). Gini Index (GI) gives users no sense of the root causes of inequality (complex and multiple) and are not actionable. However, GI is instrumental for international comparison in low-resolution.

FIGURE 5

GROWTH RATE AND GROWTH VOLATILITY

\begin{tabular}{|c|c|c|c|}
\hline & Average & Average & \\
\hline Per Capita & Positive & Negative & Percent \\
\hline Income & Growth & Growth & Positive \\
\hline in 2000 & Rate & Rate & Years \\
\hline Over $\$ 20 \mathrm{~K}$ No oil & 0.0388 & -0.0233 & 0.84 \\
\hline$\$ 15$ to $\$ 20 \mathrm{~K}$ & 0.0559 & -0.0425 & 0.76 \\
\hline & & & \\
\hline$\$ 10$ to $\$ 15 \mathrm{~K}$ & 0.0527 & -0.0407 & 0.71 \\
\hline$\$ 5$ to $\$ 10 K$ & 0.0525 & -0.0459 & 0.73 \\
\hline$\$ 2$ to $\$ 5 \mathrm{~K}$ & 0.0539 & -0.0475 & 0.66 \\
\hline$\$ .3$ to $\$ 2 \mathrm{~K}$ & 0.0537 & -0.0538 & 0.56 \\
\hline
\end{tabular}

Source: Elaboration based on North, Walls and Weingast (2009, pg. 8). Developing countries (low per capita income) grows faster than developed countries (high per capital income), but recessions are more pronounced (average negative growth rate) and positive growth years are less common (percent positive years), lacking "steadiness". 


\section{FIGURE 6}

\section{CORRELATION BETWEEN INTERPERSONAL TRUST AND GINI COEFFICIENT}

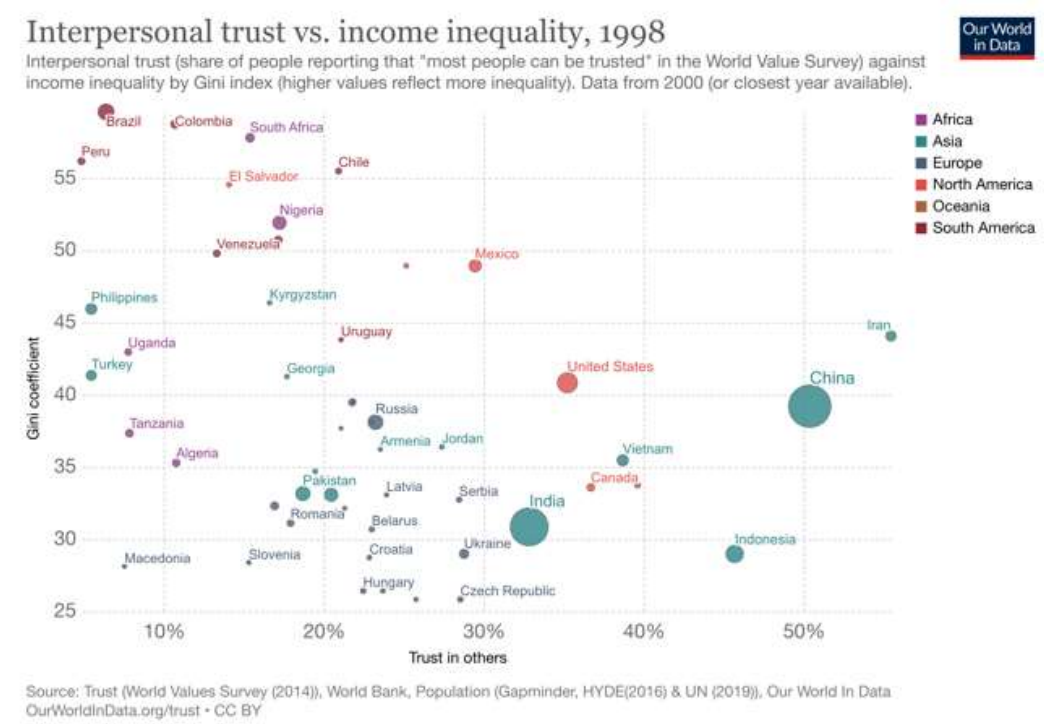

Source: ourworldindata.org/trust (base: 1998, data: 2000, retrieved: 2020). High concentration of countries around first quadrant (high inequality and low interpersonal trust) and absence of countries in second quadrant (high inequality and high interpersonal trust) indicates inverse correlation between inequality and trust in others. 